\author{
Beata Larenta-Boguska \\ badaczka niezależna \\ e-mail: beata.larenta@op.pl \\ ORCID: 0000-0002-7375-0422
}

\title{
Wokół śmierci Witkacego. Gwiazda Piołun Władysława Lecha Terleckiego z 1968 roku
}

Marta Wyka w swoich uwagach o witkacologii napisała w 2003 roku, że ,jedną z najlepszych polskich powieści, która za punkt wyjścia przyjęła los Witkacego jest Gwiazda Piołun ${ }^{1}$ Władysława Terleckiego, kompletnie dziś, jak większość dorobku tego pisarza, zapomniana” ${ }^{2}$. Zgadzając się z powyższą opinią, chciałabym się zastanowić nad tym, jak bohater wzorowany na Witkacym, pisarzu kojarzonym z ideą katastrofizmu i niepokojem metafizycznym w epoce nowoczesności, został przedstawiony w powieści z 1968 roku? Skąd Terlecki mógł czerpać inspiracje? Na ile wyczuwalna jest w tym utworze atmosfera późnych lat 60. XX wieku, a więc schyłku okresu gomułkowskiego w PRL-u? Witkiewicza odkrywano dopiero w następstwie odwilży, w 1962 roku został zaprezentowany czytelnikom w dwutomowym wydaniu dramatów, co przyczyniło się do pobudzenia zainteresowania autorem Szewców wśród twórców teatralnych, w środowiskach naukowych i studenckich.

Wprawdzie bohater powieści - malarz, filozof i pisarz - jest bezimienny, nie ma jednak wątpliwości, że w Gwieździe Piołun Terlecki wykorzystał ele-

\footnotetext{
1 Roboczy tytuł powieści brzmiał Apokalipsa. Ustaliła to Anna Jamrozek-Sowa na podstawie: Archiwum PIW-u, teczka 3439, Wniosek o publikację powieści pt. Apokalipsa, 18 VI 1968. Zob. A. Jamrozek-Sowa, "Gwiazda Piołun” (1968), w: tejże, Maski historii, strzępy wspótczesności. Studium o biografii i twórczości Władysława Lecha Terleckiego, Rzeszów 2018, s. 254.

2 M. Wyka, Ogień, piotun i kurz, „Tygodnik Powszechny” 26.10.2003, https://www.tygodnik powszechny.pl/ogien-piolun-i-kurz-122711 [dostęp 10.10.2018].
} 
menty biografii Stanisława Ignacego Witkiewicza. Ucieczka Witkacego z kochanką Czesławą Oknińską-Korzeniowską w tłumie uchodźców na wschód i jego samobójcza śmierć w Jeziorach na Polesiu 18 września 1939 roku stanowią oś fabularną utworu. Chociaż Terlecki nie zaprzeczał temu, że istnieje związek między wydarzeniami powieściowymi a biografią autora Pożegnania jesieni, nie zgadzał się jednak na lekturę powieści według kodu biograficznego. W słowie wstępnym uprzedzał:

Czytelnika proszę, aby nie odbierał tej książki jako utworu biograficznego. Bohaterowie moi przypominają postacie historyczne. Prawdziwa jest również historia $\mathrm{w}$ tej powieści przedstawiona. Zdarzyła się ona naprawdę, ale zamiarem moim nie było odtworzenie jakiegokolwiek prawdopodobieństwa między tym, co zostało $\mathrm{w}$ powieści zawarte, a owym niezmyślonym historycznym faktem $[\ldots]^{3}$.

Mimo że Gwiazda Piołun nie jest powieścią biograficzną, wpisuje się w PRL-owską recepcję filozofii, twórczości i biografii Witkacego. Terlecki niewątpliwie zakładał, że czytelnik inteligencki, do którego adresował swoje niełatwe $\mathrm{w}$ lekturze utwory ${ }^{4}$, rozpozna $\mathrm{w}$ jego bohaterze rysy wydobywanego z zapomnienia pisarza, a w atmosferze Gwiazdy Piołun - witkacowskie klimaty katastroficzne. Recenzenci powieści ${ }^{5}$ zgodnie wskazywali, że pierwowzorem głównego bohatera jest Witkacy, ale nie dokumentowali bliższych relacji między postacią literacką a rzeczywistym pisarzem-artystą-filozofem cytatami z jego utworów czy przywoływaniem szczegółów biograficznych. Witkacy funkcjonował $w$ tych recenzjach jako dekadent i katastrofista przejęty upadkiem kultury europejskiej. Nie wspominali, że ważną okolicznością jego śmierci była agresja Związku Radzieckiego na Polskę 17 września 1939 roku. Ze względów cenzuralnych nie mogły się pojawić w recenzjach np. nawiązania do głośnej książki Czesława Miłosza - Zniewolony umysł (Paryż 1953), traktującej o pisarzach $\mathrm{w}$ systemie totalitarnym. W pierwszym eseju pt. Murti-Bing Miłosz pokazywał aktualność „dziwnej książki”, czyli

\footnotetext{
3 W. Terlecki, Gwiazda Piołun, Warszawa 1968 (obwoluta). Cytując powieść oznaczam ją skrótem GP, numer strony podaję $\mathrm{w}$ nawiasie bezpośrednio po cytacie.

4 Terleckiemu jako pisarzowi inteligenckiemu poświęciłam pracę doktorską: Władysław Lech Terlecki - pisarz inteligencki schyłkowego PRL-u (w kręgu wybranych powieści oraz wypowiedzi dyskursywnych). Niniejszy artykuł jest skróconą wersją jednego z rozdziałów.

5 P. Kuncewicz, Apokalipsa według Terleckiego, „Współczesność” 1969, nr 3, s. 5; W. Maciąg, Próg tajemnicy, „Nowe Książki” 1969, nr 7, s. 449; H. Zaworska, Piołun, „Twórczość” 1969, nr 11, s. 115-119; K. Korotyńska, Mówi Władystaw Terlecki, „Literatura” 1972, nr 19, s. 19; Z. Umiński, Szosa lubelska, „Kierunki” 1975, nr 2, s. 10; M. Kociołkowski, „Gwiazda Piołun” na wrześniowych drogach", „Życie Literackie" 1984, nr 14, s. 10.
} 
wydanego w 1930 roku Nienasycenia. Analizując działanie powieściowych tabletek szczęścia Murti-Bing, poeta, który właśnie uciekł na Zachód, odsłaniał mechanizm zniewolenia obowiązujący w systemie komunistycznym i prowadził do konkluzji, że „wizja Witkiewicza spełnia się dzisiaj w najdrobniejszych szczegółach" ${ }^{6}$. W świetle jego interpretacji Witkacy uciekał w śmierć przed systemem totalitarnym, wybierał wolność za cenę życia. Wydaje się, że spojrzenie Miłosza mogło odegrać pewną rolę w krystalizacji ujęcia Terleckiego.

Recenzenci Gwiazdy Piołun nie komentowali również tematyki żydowskiej, która odgrywa w powieści ważną rolę m.in. ze względu na żydowskość towarzyszącej bohaterowi kobiety. Ten wątek ledwie się rysował $w$ recenzjach. Wydarzenia marcowe 1968 roku (rok publikacji powieści) wywołały falę antysemityzmu, która doprowadziła do emigracji wielu obywateli polskich pochodzenia żydowskiego. Najprawdopodobniej koincydencja tematu żydowskiego w powieści i wydarzeń w świecie polityczno-społecznym skłoniła recenzentów do oględności w tej sprawie. Ówczesne ograniczenia w wolności słowa z pewnością przyczyniły się do "niedoczytania” Gwiazdy Piołun, zwłaszcza że nakładały się na niejednoznaczności zakodowane w samej powieści. Jedną z nich było odniesienie głównego bohatera do Witkacego. Relacja ta nie została przez Terleckiego jasno określona, ale była niewątpliwa. Dlatego też jego powieść należy traktować jako szczególnego rodzaju świadectwo powojennej recepcji życia i dzieła Stanisława Ignacego Witkiewicza.

Samobójcza śmierć Witkiewicza stała się przedmiotem zainteresowania od momentu wydania w 1947 roku Traktatu moralnego Czesława Miłosza7. Poeta skomentował ten akt jako konsekwencję światopoglądu katastrofisty:

Wiersz mój chce chronić od rozpaczy,

Tej właśnie, jaką miał Witkacy,

Kiedy część prawdy widząc trafnie,

Sam w swoje własne wpadł zapadnie

I w owym wrześniu, pełnym żalu,

Potężną dozą weronalu

Śmierć uznał za rzecz tak zaszczytną,

Że to, co zaczął, skończył brzytwą ${ }^{8}$.

\footnotetext{
6 Cz. Miłosz, Zniewolony umyst, Kraków 1989, s. 21.

7 O niektórych próbach rekonstrukcji okoliczności śmierci Witkacego zob. S. Smoczyński, Stanisław Ignacy Witkiewicz - ostatnie dni, w: Witkacy - życie i twórczość, red. J. Degler, Wrocław 1996.

8 Cz. Miłosz, Traktat moralny, w: tegoż, Wiersze wszystkie, Kraków 2018, s. 342-343. Traktat ukazał się najpierw w „Twórczości” 1948, nr 4, s. 5-16.
} 
Zrekonstruowanie motywów samobójstwa Witkacego nastręczało jednak biografom spore trudności. Najważniejszym źródłem informacji była Czesława Oknińska-Korzeniowska, uczestniczka tamtych wydarzeń ${ }^{9}$, której relacje, powstające w pewnych odstępach czasu, różniły się znacznie od siebie. Pisała o tym Anna Micińska:

Przede wszystkim wiemy, że stało się to w obecności kobiety, która wprawdzie towarzyszyć mu miała w przeprawie przez Letę, powróciwszy jednak z połowy drogi do żywych, została jedyną osobą, która o tym poranku mogła zostawić świadectwo. Pozostawia je w istocie, aczkolwiek jest ono dość osobliwe. Czesława Oknińska, primo voto Korzeniowska, podpisująca się w ostatnich latach życia swoim przybranym secundo voto „Witkacowa”, bądź po prostu „Witkacy”, w ciągu prawie czterdziestu lat, o jakie przeżyła swojego towarzysza, zostawiła świadectwa tak różne, jak różne w rozmaitych okresach były jej stany ducha i pamięci i jak różni wreszcie byli jej rozmówcy wspomnienia te spisujący ${ }^{10}$.

Prawdopodobnie jako pierwszy wysłuchał opowieści Oknińskiej przyjaciel Witkacego, Mieczysław Choynowski, bezpośrednio po zdarzeniu w roku 1939, ale jego opracowanie historii ostatnich dni życia Witkacego ukazało się w paryskiej „Kulturze” dopiero w 1985 roku. Terlecki piszący Gwiazde Piołun w późnych latach 60. nie znał zatem tej wypowiedzi.

Sama Oknińska włączyła się do debaty o Witkacym w 1963 roku, w numerze drugim „Życia Literackiego" ${ }^{11}$. Zbigniew Przygórski w artykule Śmierć Witkacego ${ }^{12}$ oznajmiał, że dotarł do Oknińskiej, która podobno do tej pory nie chciała się wypowiadać na ten temat. Przyznawał, że wprawdzie nie stenografował jej opowieści, ale zapewniał każde słowo. Towarzyszka Witkacego miała powiedzieć:

\footnotetext{
9 Na ten temat wypowiedział się także Włodzimierz Ziemlański, którego rodzice przyjęli we wrześniu 1939 roku pod swój dach Witkiewicza (znali go jeszcze przed wojną) razem z towarzyszką (W. Ziemlański, Polesie i Witkacy, „Twórczość” 1981, nr 3). Krótką wzmiankę o śmierci Witkacego dał Jan Witkiewicz w Życiorysie St. I. Witkiewicza: „Stanisław Ignacy, podczas powszechnej wędrówki na wschód w r. 1939, podczas wojny polsko-niemieckiej, pod wpływem zbliżającej się całkowitej katastrofy wpadł w stan silnej depresji i odebrał sobie życie 18 września 1939 r." [J. Witkiewicz, Życiorys Stanisława Ignacego Witkiewicza, w: Stanisław Ignacy Witkiewicz, człowiek i twórca: księga pamiątkowa, red. T. Kotarbiński, J. E. Płomieński, Warszawa 1957, s. 349].

10 A. Micińska, Jedyne wyjście Istnienia Poszczególnego. Samobójstwo S. I. Witkiewicza, w: tejże, Istnienie Poszczególne: Stanisław Ignacy Witkiewicz, oprac. J. Degler, Wrocław 2003, s. 278.

11 Z. Przygórski, Śmierć Witkacego, „Życie Literackie” 1963, nr 2, s. 12.

12 Obejrzana w 1959 roku wystawa prac Witkacego zainspirowała go do zbadania okoliczności jego śmierci.
} 
Tak się złożyło [...] że w pierwszych dniach wojny opuściliśmy z Witkiewiczem Warszawę i skierowaliśmy się z wielotysięczną falą uchodźców na wschód. Po dwóch tygodniach pieszej męczącej tułaczki dotarliśmy do miejscowości Jeziory na Polesiu. Zatrzymaliśmy się na skraju lasu dla wypoczynku. Tam Witkiewicz oświadczył, że postanowił odebrać sobie życie. Wojnę, która dopiero się zaczęła, a której barbarzyństwa miał już dość, uważał za kataklizm, który zmiecie z powierzchni ziemi wszelką cywilizację i kulturę. [...] Była to więc decyzja całkowicie wyrozumowana, pozornie logiczna i konsekwentna, zgodna z jego postawą filozoficzną, wolna od jakiegokolwiek zabarwienia emocjonalnego, jakie zwykle towarzyszy tego rodzaju postanowieniom. Zaproponował, abym uczyniła to samo [...]. Chciał tego ${ }^{13}$.

Według wspomnień zapisanych przez Przygórskiego Oknińska próbowała odwieść Witkacego od samobójczych myśli, by ratować jego i swoje życie, ale w końcu mu uległa, chociaż nie przekonał jej do swoich racji. Wypiła przygotowaną dla niej truciznę, Witkacy podciął sobie żyły na rękach i na szyi. Czesława twierdziła, że uratowali ją przechodzący w pobliżu ludzie. Witkacy został pochowany w miejscu śmierci, gdzie postawiono zamówiony (i opłacony) przez Oknińską u kowala krzyż z imionami i nazwiskiem ${ }^{14}$. Swoją opowieść zakończyła słowami: „Ludzie zabrali mnie stamtąd przemocą. Poszłam na dalszą tułaczkę. To wszystko" ${ }^{15}$. Według relacji Oknińskiej z 1963 roku samobójstwo Witkacego było wynikiem przemyślanej decyzji, zgodnej z jego filozofią.

Kolejne, późniejsze relacje ${ }^{16}$ o śmierci Stanisława Ignacego Witkiewicza różniły się między sobą w kilku zasadniczych punktach. Rozbieżności dotyczyły momentu podjęcia przez artystę decyzji o samobójstwie i jej związku z wkroczeniem sowietów do Polski (informacja bezpośrednio wyrażona o tym fakcie pojawia się tylko w paryskiej „Kulturze”), „ślubu” z Czesławą, okoliczności pochówku Witkacego i ocalenia jego towarzyszki. Wspólne dla wszystkich opowieści jest to, że Witkacy po wybuchu wojny opuścił z nią Warszawę, a w Jeziorach na Polesiu w dniu 18 września 1939 roku popełnił samobójstwo ${ }^{17}$. Niczemu, co zawiera się pomiędzy tymi granicznymi wydarzeniami, nie sposób nadać ścisłości faktograficznej. Tu więc mógł wkroczyć

\footnotetext{
13 Z. Przygórski, Śmierć Witkacego, s. 12.

14 Tamże.

15 Tamże.
}

16 Zob. T.E. Witkiewicz, Ludzie, którzy przeszli przez Muzeum Tatrzańskie w Zakopanem, „Miesięcznik Literacki" 1975, nr 2, s. 54; Cz. Oknińska, Ostatnie 13 dni życia Stanisława Ignacego Witkiewicza, „Kierunki” 1976, nr 13, s. 6; J.Z. Brudnicki, Ostatnia droga Witkacego. Wersja ostatnia, ale nie ostateczna, „Przegląd Humanistyczny” 1977, nr 10, s. 81-91; M. Choynowski, Jeszcze o śmierci Witkacego, „Kultura” (Paryż) 1985, nr 9, s. 111.

17 Samobójstwo Witkacego także poddawane było w wątpliwość - przykładem może być 
Terlecki ze swoją literacką koncepcją bez obawy, że ktoś mu zarzuci mijanie się z prawdą. Autor Gwiazdy Piołun musiał znać spisaną przez Zbigniewa Przygórskiego relację Czesławy Oknińskiej z „Życia Literackiego”, zwłaszcza że w tym samym numerze pojawiła się recenzja jego książki Pożar ${ }^{18}$. Relacja ta mogła zainspirować Terleckiego do wyeksponowania postaci kobiecej, uczynienia jej równorzędną w stosunku do bohatera męskiego, a zarazem reprezentującą inną niż on postawę wobec kataklizmu.

W Gwieździe Piołun historia bohaterów powieściowych rzeczywiście zbliżona jest do wersji spisanej przez Przygórskiego. Można też zaryzykować hipotezę, że nie tylko relacja towarzyszki Witkacego zainspirowała autora Gwiazdy Piołun, ale że z kolei powieść miała wpływ na późniejsze wypowiedzi Oknińskiej. Kobieta wprawdzie nie upodabniała swoich relacji do powieściowej wersji zdarzeń, ale Terlecki mógł ją ośmielić do „literaturyzowania” faktów.

Prezentując postać młodej kobiety, towarzyszącej głównemu bohaterowi w drodze ku samobójczej śmierci, Terlecki wskazywał na jej żydowskie korzenie, chociaż rzeczywisty pierwowzór - Czesława Oknińska - nie była Żydówką. Tak rodzinę wspominała jej siostra:

Dziadek mój i Czesławy był podobno herbowym szlachcicem, bardzo już jednak zubożałym, z kilkoma morgami pod Łukowem, w Siedleckiem. Tatuś nasz, Józef Okniński uciekł więc z domu, pojechał do Warszawy, zaczął pracować na kolei jako dyspozytor ruchu na Dworcu Głównym w Warszawie. Nie miał wykształcenia, ale był inteligentny, z zacięciem społecznikowskim, interesował się polityką, został więc prezesem związku kolejarzy. Dobrze zarabiał i po przejściu na emeryturę kupił plac w Kobyłce pod Wołominem, zbudował dom, gdzie się przenieśliśmy i gdzie zmarł w pierwszych dniach września 1939 roku ${ }^{19}$.

Przedstawienie towarzyszki artysty jako Żydówki jest niewątpliwie celowym autorskim zabiegiem. Warto więc zastanowić się, czemu ten zabieg służy?

Bohaterka powieści $\mathrm{w}$ czasie wędrówki na wschód wspomina swoją przeszłość: „Ojciec mój - mówi - był lekarzem w małym żydowskim miasteczku. Tam się urodziłam i stamtąd pochodzą pierwsze zapamiętane obrazy" [GP, s. 110]. Opowiada o niedzielnym spacerze wynajętą bryczką,

film Jacka Koprowicza z 2010 roku Mistyfikacja. Twórca tłumaczy jednak, że filmowy obraz pokazujący życie Witkacego (w PRL-u, w 1969 roku), ukrywanego przez Czesławę Oknińską, nie jest jednoznaczny; można odczytać go bowiem jako wytwór schizofrenicznej osobowości kochanki. Por. Witkacy! Zrób coś, z Jackiem Koprowiczem rozmawia Beata Zatońska, TVP.INFO (publikacja 09.04.2010), http://www.tvp.info/1635789/witkacy-zrob-cos [dostęp 12.10.2017].

18 Por. W. Maciąg, Wojna i subtelności wrażliwej duszy, „Życie Literackie” 1963, nr 2, s. 11.

19 J. Siedlecka, Wikacowa, w: tejże, Mahatma Witkac, Warszawa 2005, s. 148. 
o śpiewie, o radości, ale też przytacza refleksje ojca o śmierci. We wspomnieniach bohaterki powracają także rozważania ojca nad mechanizmami życia społecznego. $\mathrm{W}$ rozmowie $\mathrm{z}$ wnukiem kantora mówi:

Kiedy w tartaku następują dłuższe przestoje i zaczyna grozić bezrobocie, uważają, że jedna solidna szubienica w każdym mieście - tam gdzie są prawdziwe fabryki również, ale i tutaj, gdzie takich fabryk nie ma i gdzie żyć z rzemiosła trudno - że jedno takie drzewo - o, jak pięknie w ich oczach zakwitające! - wystawione na postrach przepędzi zło raz na zawsze. A kilku wisielców skoro każde drzewo musi mieć owoc, niech ma i ono - znalazłoby się. A nędzę pochowałoby się z nimi. W tym sęk, że wróci... [GP, s. 113]

Znalezienie kozła ofiarnego, którego można obarczyć odpowiedzialnością za zło, jest według niego sposobem rządzących na utrzymanie władzy. Ludzie doświadczający biedy są sfrustrowani, chętnie więc oskarżą obcego o sprawstwo. Mechanizm jest zawsze ten sam.

Powieściowy wnuk kantora mówi o propagandzie antyżydowskiej. Ojciec dziewczyny, wyjaśniając swoje stanowisko wobec nędzy, podkreśla, że trzeba z nią walczyć w inny sposób: „Wierzyć w rozum ludzki. Nie upajać się szubienicami. Nie budzić nienawiści..." [GP, s. 113]. Odpowiedź rozmówcy na te pobożne życzenia jest ironiczna: „Oj, jak oni nas kochają" [GP, s. 113]. Wskazuje na trwałość przeciwstawiania Żydów nie-Żydom.

Matka bohaterki nazywa wnuka kantora ćmą lecącą do ognia. Ognia nie można wprawdzie jej zdaniem uniknąć, ale „czemu my, Żydzi - pyta - musimy się o tym przekonać najpierw?" [GP, s. 115]. Żydzi jej zdaniem są więc niejako predestynowani do ekstremalnych doświadczeń dziejowych. Nadciągająca katastrofa najpierw dotyka ich, potem zagarnia innych.

W powieści Terleckiego ujawnia się problem narastającego przed wojną antysemityzmu. Towarzyszka artysty wspomina swoje spotkanie z pewnym Amerykaninem współpracującym z organizacją syjonistyczną, zainteresowanym kwestią żydowską w Polsce oraz stosunkiem polskich władz do emigracji. Dziewczyna przełożyła broszurę, w której przedstawiano plany emigracji żydowskiej:

Żydzi nie mogą i nie powinni stawać się Polakami. Na załatwienie sprawy żydowskiej jest tylko jeden sposób: wyjazd z Polski przynajmniej trzech milionów Żydów [...] i to nie w przeciągu długiego czasu, ale przez kilka lat... [GP, s. 94]

Amerykanin mówił o zbliżającej się nieuchronnie wojnie, w której „trzeba się liczyć z akcjami represyjnymi wobec Żydów w takiej skali, w jakiej one dawno nie występowały" [GP, s. 96]. Podkreślił także, że emigracja Żydów obejmuje nie tylko Polskę, ale cały świat. 
Snująca swoje wspomnienia towarzyszka artysty nie mogła się pogodzić z projektowaną niejako odgórnie emigracją. Pytała Amerykanina: „Kto wam dał prawo do decydowania o naszym losie?..." [GP, s. 98]. W odpowiedzi usłyszała: „Spełniamy utajone marzenia, którym ludzkość daje nieśmiało wyraz. [...] Wracajmy tam, skądeśmy przyszli. Wybierajmy mniejsze zło..." [GP, s. 98]. Bohaterka, mimo perswazji syjonisty, nie decyduje się na wyjazd, myśli o studiach w Polsce. Amerykanin nie rozumie decyzji dziewczyny i zarzuca jej bezsensowny tradycjonalizm:

Zachowuje się pani jak starzy ortodoksyjni Żydzi z małych wschodnich miasteczek, dla których świat kończy się za najbliższą rogatką. Którym niczego nie można wytłumaczyć, bo posługują się językiem, jakim można było mówić w innej epoce. Oni również uważają, że tu jest właśnie ich miejsce [GP, s. 99].

Problem emigracji Żydów porusza także główny bohater, wyznając, że dostał ważny list, na który nie zdążył odpisać, ani nie spełnił zawartej w nim prośby:

Pisał z Paryża pewien znajomy Żyd. Dawno wyjechał z Warszawy. Zapomniałem, że istnieje. Prosił o sprawdzenie adresów rodziny, która kiedyś mieszkała na Nalewkach, ale podobno wyjechała z Warszawy. Można, by to jakoś ustalić [GP, s. 26].

Żyd - autor listu ${ }^{20}$ od dawna mieszkał za granicą, ale myślał o kolejnej przeprowadzce: „Pisał, że na coś się zanosi i że będzie musiał wyjechać do Kanady. A już ma własną malarską pracownię. Jakoś się urządził" [GP, s. 70]. Malarz powtarza pogłoski przywiezione przez żonę z Wiednia: „opowiadała, że oni mają zabijać ludzi zastrzykami w serce”, wspomina też przedwojenne ekscesy antysemickie w Polsce: „Mówiliśmy, że bicie Żydów pałkami to nieodpowiedzialne wybryki”. Jego towarzyszka-Żydówka dopowiada: „Od tego się zaczyna" i przywołuje znany polski autostereotyp o dawnej tolerancji w stosunku do obcych: „A przecież zawsze byliśmy tolerancyjni. Wszędzie w Europie podpalano stosy inkwizycyjne, a u nas uczono szacunku dla prześladowanych" [GP, s. 70].

Recenzenci Gwiazdy Piołun, jak wspomniałam, nie zagłębiali się w kwestię żydowską, mimo że sposób jej potraktowania zasługiwał na podkreślenie. Problem przedwojennej emigracji żydowskiej, syjonizmu nieczęsto przecież pojawiał się w PRL-owskiej literaturze. Kontekst polityczny roku 1968,

20 Prawdopodobnie Terlecki uwzględnił konkretną postać, ale Żydów malarzy, którzy wyjechali przed wojną z Polski było wielu. Być może chodzi o Aleksandra (Saszę) Blondera. 
w którym ukazała się powieść Terleckiego, nagonka antysemicka rozpętana przez władze, uczynił Gwiazdę Piołun utworem dziwnie aktualnym. Korespondowały $\mathrm{z}$ nią apokaliptyczne nastroje $\mathrm{w}$ powieści związane $\mathrm{z}$ nadchodzącą zagładą. Propagandowe hasło zwalczania spisku syjonistycznego skutkowało wyrzucaniem Żydów z PZPR, pozbawianiem ich pracy między innymi $\mathrm{w}$ oświacie, służbie zdrowia, nauce. $\mathrm{Ci}$, którzy tworzyli polskie powojenne społeczeństwo, a $\mathrm{w}$ dużej mierze kształtowali elitę intelektualną, musieli wyjechać z kraju ${ }^{21}$.

Książka Terleckiego wprost nie odwołuje się do wydarzeń związanych z Marcem '68 roku, ale ponieważ wydana została blisko tej daty, ówczesny czytelnik nie mógł traktować wątku żydowskiego w powieści jako kwestii wyłącznie historycznej. Terlecki odróżniał Żydów identyfikujących się z miejscem swego urodzenia i życia oraz syjonistów, czy też tych, do których trafiała propaganda syjonistyczna. W prasie z roku 1968 i na specjalnie organizowanych wiecach mówiono o syjonistach jako wrogach Polski Ludowej. Bohaterka Gwiazdy Piołun - Żydówka sceptycznie wypowiadała się o syjonistach, nie miała zamiaru wyjeżdżać z Polski. Nie uciekła za granicę, kiedy było to jeszcze wykonalne.

Temat przedwojennej emigracji żydowskiej łączy się z tematem nadrzędnym $\mathrm{w}$ powieści, to znaczy $-\mathrm{z}$ ucieczką. Bohaterów powieści Terleckiego określa przede wszystkim to, że są uciekinierami. Propaganda komunistyczna wykorzystywała motyw ucieczki wrześniowej władz państwowych, żeby skompromitować sanacyjny rząd i całą II Rzeczpospolitą. Terlecki pokazał tłumy uchodźców, a malarz, pisarz i filozof ${ }^{22}$, jak jego pierwowzór Witkacy, uciekający przed wojną, nie różni się niczym od innych ludzi; indywidualna jednostka twórcza staje się częścią tłumu ogarniętego lękiem: „ten lęk rozciąga się nad nimi nikogo nie wyróżniając. Każdego obejmując z taką samą siłą. Łącząc ich według sprawiedliwego porządku. Słabych i silniejszych" [GP, s. 138]. Tłum zagarnia różnych ludzi - jak pisze Gustave Le Bone - w jedną „zbiorową duszę", która powstaje poprzez zanik odrębności jednostek ${ }^{23}$. Artysta odczuwa boleśnie takie sprowadzenie do poziomu elementarnego lęku przed śmiercią. Jest nim upokorzony. Ten, który wyznaczał sobie niezwykle ważną funkcję budzenia uczuć metafizycznych w zmaterializowanym i zautomatyzowanym nowoczesnym świecie, staje się takim

\footnotetext{
21 J. Eisler, Emigracja pomarcowa, w: tegoż, Polski rok 1968, Warszawa 2006, s. 117.

22 Zob. M. Soin, Filozofia Stanisława Ignacego Witkiewicza, Wrocław 2002; J. Błoński, Witkacy na zawsze, Kraków 2003.

23 Por. G. Le Bon, Psychologia tłumu, przeł. B. Kaprocki, Warszawa [b.r.w.], s. 12 (pierwsze wydanie książki pochodzi z roku 1895).
} 
samym uciekinierem, jak inni opuszczający w popłochu swoje domy. Używając określeń Le Bone’a, można powiedzieć, że bohater obawia się bycia częścią tłumu:

Każda jednostka, stając się cząstką tłumu, zstępuje tym samym o kilka stopni niżej w swym rozwoju kulturowym. Jako jednostka posiada pewną kulturę, w tłumie zaś staje się istotą dziką i niewolnikiem instynktów ${ }^{24}$.

Narracja prowadzona w trzeciej osobie, ale blisko świata przedstawionego umożliwia czytelnikowi obserwację bohaterów wśród innych uchodźców i w zetknięciu z ludźmi, których jeszcze nie porwała fala strachu:

Na chodnikach mijali grupy uciekinierów. Między nimi przechodzili ludzie ubrani odświętnie. Dziwny kontrast, jakby w święto odbywał się wielki jarmark. [...] Senne niedzielne popołudnie w ostrym słońcu. [...] Przy stolikach, wystawionych do ogrodu, gromadzili się zmęczeni, rozdrażnieni ludzie. Obok stały ich toboły i walizki. Dzieci spały na rozłożonych kocach [GP, s. 130].

Uciekinierzy wchodzą między ludzi, którzy są jeszcze na swoim miejscu i żyją zwykłym rytmem, rozróżniają dni świąteczne od codzienności. Bohater i jego towarzyszka niejednokrotnie korzystają z gościny i uprzejmości osób spotkanych po drodze. Niejedna wieś położona na trasie uciekinierów udziela noclegu i jedzenia strudzonym wędrowcom: "Jedli. Odpoczywali. Wodę brali za darmo" [GP, s. 16].

Ludzie zatracają w ucieczce swoje człowieczeństwo, mieszają się ze zwierzętami i rzeczami:

Od pewnego czasu krzyk, który im towarzyszył, wzmógł się. [...] nie można już było odróżnić głosów ludzi i zwierząt, skrzypienia kół i klaksonów. [...] Było i tak, że słabsi odpadali. Zsuwali się z nasypu pomiędzy porzucone walizki i rozprute pierzyny, połamane rowery. I leżeli w trawie z głowami wciśniętymi w cień [GP, s. 137].

Szanse na przeżycie mają silniejsi. Ludzie niezdolni do dalszej ucieczki wypadają z tłumu na pobocze, przypominając porzucone, bezwartościowe przedmioty. Narracja podkreśla perspektywę bohaterów, ich udrękę związaną z koniecznością podporządkowania się tłumowi:

To było najgorsze, że teraz posuwali się coraz wolniej. Krok za krokiem. Obrót koła za obrotem. Kopyta końskie, nogi, szprychy. Szli przed oddziałem konnym. I nic nie można było zrobić, aby przecisnąć się naprzód. Jeżeli ktoś

24 Tamże, s. 18. 
chciał przejść, musiał trzymać się drogi. Nie odpadać. Tkwić w tym pierścieniu [GP, s. 136-137].

Bohaterowi brakuje sił. Jego młoda towarzyszka ma ich więcej: "Gdyby nie to, że podtrzymywała go, upadłby na pewno. Nie starczyłoby sił, żeby się podnieść. Staranowaliby go" [GP, s. 141]. Wycieńczony artysta jest o krok od śmierci w tłumie.

Witkacy, jak wiadomo, obawiał się zaniku uczuć metafizycznych w następstwie mechanizacji społeczeństwa. W Gwieździe Piołun czytelnik obserwuje ludzi zredukowanych do odruchu instynktownej ucieczki, walki o życie w sensie biologicznym. Powieść przedstawia "ślepy pęd ludzi i bydła” [GP, s. 24]. Bohaterowie uciekają i równocześnie tkwią w pułapce. Kiedy zatrzymują się, żeby odpocząć, dogania ich następna fala uciekinierów:

Przez jakiś czas droga, przy której odpoczywali, była pusta. Z rzadka jedynie toczyły się po niej załadowane wozy. Duża grupa uciekinierów oddaliła się. Chmura kurzu opadła. Ale niebawem pojawili się następni. Zmęczenie nie mijało. [...] Za dużo spraw nachodziło na siebie, zbyt wiele powstawało pytań. Nie, to nie był odpoczynek [GP, s. 115].

Na fizyczne trudy nakładają się wspomnienia z przeszłości bohatera, jego pobytu w Rosji w czasie rewolucji. To nie pierwsza ucieczka w jego życiu, nie pierwszy koniec świata, jaki przeżywa. Czy to znaczy, że historia się powtarza? Z powieści Terleckiego można wnioskować, że kataklizm historyczny dopada w końcu tych, którym wcześniej udało się uciec.

Bohatera powieści łączy z Witkacym pobyt w rewolucyjnej Rosji. Dzisiaj o doświadczeniach rosyjskich pisarza sporo już wiadomo, nie ma wątpliwości, że wywarły na niego ogromny wpływ ${ }^{25}$. W latach poprzedzających publikację Gwiazdy Piołun nie był to jeszcze temat opracowany. Nie był też wygodny do omawiania. Koncepcja Terleckiego stanie się lepiej widoczna, kiedy ją zestawimy z wypowiedzią Jarosława Iwaszkiewicza z 1976 roku o Witkacym w Rosji. Iwaszkiewicz powoływał się na zdanie Andrzeja Mencwela:

był to dla niego moment przełomowy, wstrząs, katharsis, która zmieniła jego całe dotychczasowe życie, spowodowała reorientację poglądów i uczuć. [...] Witkacy rodzi się Witkacym właśnie w Rosji czasów rewolucji ${ }^{26}$.

\footnotetext{
25 Zob. m.in. A. Micińska, Witkacy w Rosji, „Twórczość” 1985, nr 4, s. 66-90.

26 Na słowa Andrzeja Mencwela powołuje się Iwaszkiewicz bez określenia konkretnego źródła [zob. J. Iwaszkiewicz, Witkacy, w: tegoż, Petersburg, Warszawa 1976, s. 59].
} 
Analizował znaczenie Petersburga dla rozwoju duchowego polskiego pisarza. Podkreślał rozmach zastanej tam przez Witkacego kultury (muzea potężniejsze niż "galicyjska mizeria"):

poczuł się nie tylko artystą, ale i filozofem, znalazł swoje miejsce na ziemi. Tym boleśniejszy będzie konflikt tej świadomości z całkowitym zlekceważeniem go przez społeczeństwo polskie. Witkacy był doprowadzany do samobójstwa stopniowo ${ }^{27}$.

Według Iwaszkiewicza rzeczywistość polska po 1918 roku rozczarowała Witkacego, a nawet pośrednio doprowadziła do samobójstwa. Doświadczenie rosyjskie w tym zestawieniu było budujące. Próbując zrekonstruować poglądy autora Szewców na rewolucję, Iwaszkiewicz stwierdzał wymijająco, że trudno tu o jednoznaczną opinię $e^{28}$.

Rosyjska przeszłość bohatera Terleckiego składa się z innych obrazów niż później przedstawiona przez Iwaszkiewicza Rosja Witkacego. Kiedy bohater Gwiazdy Piołun powraca do wspomnień rosyjskich, przypomina sobie zwłaszcza „bezruch":

Wiele lat temu, w głębi Rosji, na krótko przed powrotem do kraju, w małej, opuszczonej już przez białe wojska miejscowości ogarnęło go po raz pierwszy podobne uczucie. Teraz to sobie przypominał idąc przez pusty plac. [...] Dziś wyglądało to bardzo podobnie. [...] Martwota. Kiedy przesunął mu się przed oczyma ten sam obraz, z którego wtedy nie mógł się długo otrząsnąć, pomyślał, że $w$ takich okazjach zawsze czas sprawia zaskakujące niespodzianki. Żyje się w gwałtownym piekle albo znów, dla odmiany, ogarnia człowieka zupełny bezruch. Te oszałamiające obroty czasu, kiedy granica między obłąkanym ruchem a całkowitym zastojem jest nieuchwytna... [GP, s. 189-190]

„Bezruch”, który bohater zapamiętał z rewolucyjnej Rosji, został wywołany $\mathrm{w}$ jego pamięci widokiem pustego placu, kontrastującego z panicznym ruchem uciekinierów. Uruchomiło to refleksję nad „oszałamiającymi obrotami czasu" - nagłymi przyspieszeniami i równie nagłymi zatrzymaniami, prowadzącą do doznania absurdu.

Informację o wkroczeniu Armii Czerwonej do Polski Terlecki w swojej powieści wkłada w usta polskiego urzędnika: „nie ma już wschodniej granicy. Dla ochrony miejscowej ludności wkracza wojsko stamtąd... [...] Ale czy to nie mogło się zdarzyć? [...] Chcą się zabezpieczyć" [GP, s. 201]. Znamienne,

27 Tamże.

28 Tamże, s. 60. 
że urzędnik podaje oficjalny, rozgłaszany przez sowiecką propagandę powód przekroczenia granicy z Polską. Przekaz został jedynie opatrzony komentarzem: „niedobre wiadomości”. Z punktu widzenia urzędnika oznaczają one zakończenie jego czynności na rzecz mieszkańców: dotąd robił, co mógł dla obrony miasta, by nadal funkcjonowały w nim sklepy i instytucje. W reakcji na tę wiadomość bohater stwierdza: „Jeszcze jeden ogromny, niszczący pogrom. Nie chcę w nim uczestniczyć. To wszystko. Mam podwójne prawo, aby tak myśleć..." [GP, s. 208-209]. O świcie obserwuje miasteczko nazajutrz po agresji wschodniego sąsiada: „Wiszą teraz nad nimi [nad sklepami - dop. B.L.B.] długie czerwone proporce. Pewnie zawiesili je w nocy" [GP, s. 220-221]. Utwierdza się w przekonaniu o beznadziejności sytuacji: „Wiem teraz, że nic się nie zmieni” [GP, s. 208]. Po raz kolejny mówi kobiecie, która mu towarzyszy, o strachu: „Boję się. Najgorszy rodzaj strachu. Nie boję się o siebie” [GP, s. 208]. Słyszy od niej zapewnienie: „Postaram się, aby ten lęk minął. Mamy przecież jeszcze czas. Trochę go mało, ale wystarczy" [GP, s. 208]. Spędzają ostatnie chwile razem, przygotowując się do wspólnej śmierci. Powieściowy artysta ucieka w śmierć przed światem, którym zawładnął „pogrom”. Użył słowa kojarzącego się przede wszystkim z wybuchami antysemityzmu, ale nadał mu ogólniejsze znaczenie. Bohater Gwiazdy Piołun radykalnie odrzucił rzeczywistość, której kontynuację stanowiły również czasy po 1945 roku. Fala antysemityzmu z roku 1968 była na to dowodem.

Zestawiając Gwiazdę Piołun z późniejszymi dziełami Terleckiego, możemy stwierdzić, że jest to pierwsza spośród jego powieści, w której głównym bohaterem jest pisarz. W latach 80. i 90. powstały kolejne: Zwierzęta zostały opłacone (1980), Cień karła, cień olbrzyma (1983), Pismak (1987), Cierń i laur (1989), Zabij cara (1992). Ludzie pióra w tych utworach musieli się mierzyć z sytuacją zagrożenia, trudnego wyboru, strachu, osaczenia. Ucieczka stanowiła główny motyw nie tylko w Gwieździe Piołun. Uciekał również Lew Tołstoj z powieści Cień karta, cień olbrzyma, a także - do pewnego stopnia wzorowany na Józefie Ignacym Kraszewskim pisarz z Ciernia i lauru.

O Gwieździe Piołun autor wypowiedział się ostatni raz w wywiadzie z 1997 roku. Nazwał ją wówczas książką o strachu ${ }^{29}$. Stwierdzał, że to strach bohatera „w konsekwencji prowadzi do śmierci samobójczej i do wzięcia odpowiedzialności za śmierć drugiego człowieka” i dodawał: „jeśli można kogoś rozgrzeszyć za samobójstwo, to nie można za wpędzanie kogoś drugiego

29 Por. Finezje literackie. Wtadysław Terlecki, rozmawiała Lidia Nowicka, Polskie Radio, 1997, cz. 1-4. 
w śmierć" ${ }^{30}$. Terlecki tłumaczył więc, że przyjmuje w powieści stanowisko polemiczne wobec Witkacego czy raczej wobec jego ostatnich życiowych wyborów i decyzji. Można stąd wnioskować, że sam Terlecki nie chciał być pisarzem, który swoich czytelników w coś „wpędzał”, narzucał im swoje emocje. Poruszał w tym wywiadzie kwestię odpowiedzialności pisarza, który ma możliwość manipulowania cudzymi emocjami, ale z niej nie korzysta. Postać wzorowana na Witkacym była mu potrzebna do przemyślenia tych kwestii również na własny użytek.

\section{Bibliografia}

Błoński Jan (2003), Witkacy na zawsze, Kraków: Wydawnictwo Literackie.

Brudnicki Jan Z. (1977), Ostatnia droga Witkacego. Wersja ostatnia, ale nie ostateczna, „Przegląd Humanistyczny", nr 10, s. 81-91.

Choynowski Mieczysław (1985), Jeszcze o śmierci Witkacego, „Kultura” (Paryż), nr 9, s. $107-113$.

Eisler Jerzy (2006), Emigracja pomarcowa, w: J. Eisler, Polski rok 1968, Warszawa: Instytut Pamięci Narodowej, s. 95-131.

Iwaszkiewicz Jarosław (1976), Witkacy, w: J. Iwaszkiewicz, Petersburg, Warszawa: PIW, s. 27-33.

Jamrozek-Sowa Anna (2018), "Gwiazda Piołun" (1968), w: A. Jamrozek-Sowa, Maski historii, strzępy wspótczesności. Studium o biografii i twórczości Władystawa Lecha Terleckiego, Rzeszów: Wydawnictwo Uniwersytetu Rzeszowskiego, s. 254-265.

Le Bon Gustave (b.r.w.), Psychologia tłumu, przeł. B. Kaprocki, Warszawa: Drukarnia Artystyczna Saturnina Sikorskiego.

Maciąg Włodzimierz (1963), Wojna i subtelności wrażliwej duszy, „Życie Literackie”, nr 2, s. 11.

Micińska Anna (1985), Witkacy w Rosji, „Twórczość", nr 4, s. 66-90.

Micińska Anna (2003), Jedyne wyjście Istnienia Poszczególnego. Samobójstwo S. I. Witkiewicza, w: A. Micińska, Istnienie Poszczególne: Stanistaw Ignacy Witkiewicz, oprac. J. Degler, Wrocław: Wydawnictwo Dolnośląskie, s. 277-290.

Miłosz Czesław (1989), Zniewolony umyst, Kraków: Krajowa Agencja Wydawnicza.

Miłosz Czesław (2018), Traktat moralny, w: Cz. Miłosz, Wiersze wszystkie, Kraków: Znak, s. 342-343.

Oknińska Czesława (1976), Ostatnie 13 dni życia Stanisława Ignacego Witkiewicza, „Kierunki", nr 13, s. 6-7.

Przygórski Zbigniew (1963), Śmierć Witkacego, „Życie Literackie”, nr 2, s. 12.

Siedlecka Joanna (2005), Witkacowa, w: J. Siedlecka, Mahatma Witkac, Warszawa: Słowo, s. 147-175.

30 Tamże. 
Smoczyński Sławomir (1996), Stanisław Ignacy Witkiewicz - ostatnie dni, w: Witkacy życie i twórczość, red. J. Degler, Wrocław: Wiedza o Kulturze, s. 251-262.

Soin Maciej (2002), Filozofia Stanisława Ignacego Witkiewicza, Wrocław: Wydawnictwo Uniwersytetu Wrocławskiego.

Terlecki Władysław Lech (1968), Gwiazda Piołun, Warszawa: PIW.

Witkiewicz Jan (1957), Życiorys Stanisława Ignacego Witkiewicza, w: Stanisław Ignacy Witkiewicz, człowiek i twórca: księga pamiątkowa, red. T. Kotarbiński, J. E. Płomieński, Warszawa: PIW, s. 341-350.

Witkiewicz Tadeusz Eugeniusz (1975), Ludzie, którzy przeszli przez Muzeum Tatrzańskie w Zakopanem, „Miesięcznik Literacki”, nr 2, s. 54.

Wyka Marta (2003), Ogien, piołun i kurz, „Tygodnik Powszechny” 26.10.2003, https:// www.tygodnikpowszechny.pl/ogien-piolun-i-kurz-122711.

Zaworska Helena (1973), Piołun, w: H. Zaworska, Spotkania. Szkice literackie, Warszawa: Czytelnik, s. 234-240.

\title{
About Witkacy's Death: Gwiazda Piołun by Władysław Lech Terlecki from 1968
}

\begin{abstract}
The article interprets the novel Gwiazda Piołun by Władysław Lech Terlecki. Its main character is based on the real life figure of Stanisław Ignacy Witkiewicz - author, painter, philosopher. The author of the article indicates the relationships between the accounts of Witkacy's death and its fictional version. Terlecki's story of a painter who escapes from war, only to commit suicide eventually, became a pretext for discussing the events from September 1939 and March 1968.
\end{abstract}

Keywords: biography, suicide, Polish People's Republic, antisemitism 